\title{
Bacterial numbers, bacterial production, and heterotrophic nanoplankton abundance in a warm core eddy in the Eastern Mediterranean
}

\author{
Tamar Zohary ${ }^{1}$, Richard D. Robarts ${ }^{2}$ \\ ${ }^{1}$ Y. Allon Kinneret Limnological Laboratory, Israel Oceanographic and Limnological Research Ltd. (IOLR), PO Box 345, \\ Tiberias 14102, Israel \\ ${ }^{2}$ National Hydrology Research Institute, Environment Canada, 11 Innovation Blvd., Saskatoon, Saskatchewan, Canada S7N $3 H 5$
}

\begin{abstract}
Bacterial numbers and production, and abundance of heterotrophic nanoplankton (HNAN) were recorded over $24 \mathrm{~h}$ at the core and boundary of the Cyprus Eddy, a warm-core eddy in the Levantine Basin of the Eastern Mediterranean Sea. The basin is known as one of the most oligotrophic on record. Bacterial numbers in the euphotic zone were close to the lower threshold value for bacterial abundance in the oceans, with means of $2.7 \times 10^{5}$ bacteria $\mathrm{ml}^{-1}$ at the boundary and $4.9 \times 10^{5} \mathrm{ml}^{-1}$ at the core. Bacterial production, measured as the rate of DNA labelling by thymidine (TdR), ranged from 0.01 to $0.70 \mathrm{pmol} \mathrm{TdR} \mathrm{l}^{-1} \mathrm{~h}^{-1}$, values which fall at the lower end of ranges reported from other freshwater and marine ecosystems. No diel cycles of bacterial numbers or rate of $T d R$ incorporation were observed, but the TdR rate normalized to cell numbers showed marked diel variation with the highest rates usually found in early morning hours. HNAN were characteristically small (mostly $<3 \mu \mathrm{m}$ in diameter) and more abundant in the core (37 to 850 cells $\mathrm{ml}^{-1}$ ) than in the boundary station (19 to 414 cells $\mathrm{ml}^{-1}$ ). The long bacterial doubling times (ca $50 \mathrm{~d}$ ), and the parallel distribution of bacteria and HNAN, suggested low grazing pressure. A possible alternative food source for HNAN is prochlorophytes. Higher microbial standing crop and activity are anticipated in the core of the eddy in winter, when deep mixing occurs.
\end{abstract}

\section{INTRODUCTION}

Bacteria and heterotrophic nanoplanktonic (HNAN) grazers play major roles in the cycling of organic matter and nutrients in aquatic ecosystems. In oligotrophic oceans bacteria often consume up to half of the primary production via dissolved organic matter, and are then consumed by protozoan grazers that also feed on small algae (Azam et al. 1983). Recent studies demonstrate that in oligotrophic oceans bacterial biomass often exceeds that of phytoplankton (Fuhrman et al. 1989, Cho \& Azam 1990). However, most studies have been carried out in coastal systems; those from oligotrophic offshore waters are scarce (Ducklow 1986, Fuhrman et al. 1989)

The pelagic waters of the Levantine Basin of the Eastern Mediterranean Sea have been shown to be among the most oligotrophic on record, with excep- tionally low primary productivity (Berman et al. 1984, 1986), chlorophyll and nutrient concentrations (Salihoglu et al. 1990, Krom et al. 1991), and exceptionally deep light penetration (Berman et al. 1985, Megard \& Berman 1989). To our knowledge, data on the abundance of bacteria and heterotrophic nanoplankton, and on rates of bacterial production in this oligotrophic sea have not been published.

Recent studies highlight the potential importance of mesoscale eddies as sites of episodic nutrient injections into the photic zone, leading to localized enhancement of primary productivity (Jenkins 1988, Falkowski et al. 1991). Fronts of warm core rings were shown to sustain high bacterial abundance and activity (Ducklow 1986). Recently, Brenner (1989) and Brenner et al. (1991) described a persistent warm-core eddy located south of Cyprus (the Cyprus Eddy) in the Levantine Basin. Krom et al. (1992) reported enhanced primary produc- 
tivity in the core of the Cyprus Eddy in winter, as a result of deep mixing, and as was observed in the core of other warm-core eddies (Tranter et al. 1980, Bradford et al. 1982).

Our study constituted part of an effort organized by GAP (Group on Aquatic Productivity) to measure for the first time a range of microbiological parameters in the Cyprus Eddy and to compare organism abundances and rate processes between the eddy's core and its boundary. Waters in the core of the eddy were to a large extent sealed off from the surrounding water (Brenner et al. 1991, Krom et al. 1992). Measurements taken over $24 \mathrm{~h}$ in the core were therefore likely to follow diel patterns in the same water parcel except, perhaps, at the surface (ca 0 to $40 \mathrm{~m}$ ) mixed layer. We report here our findings on the abundance and production of bacteria, and on the abundance of HNAN, their potential grazers, over 24 h cycles.

\section{METHODS AND STUDY SITE}

The study was conducted aboard the RV 'Shikmona' during a GAP/IOLR cruise to the Cyprus Eddy. A station located at the boundary of the eddy $\left(34^{\circ} 23^{\prime} \mathrm{N}\right.$, $33^{\circ} 44^{\prime} E_{i}$ maximum depth $586 \mathrm{~m}$ ) was occupied on 11-12 September 1989, and a station at its core $\left(33^{\circ} 43^{\prime} \mathrm{N}, 35^{\circ} 30^{\prime} \mathrm{E}_{\mathrm{i}}\right.$ maximum depth $\left.2200 \mathrm{~m}\right)$ on 13-14 September 1989. Water samples were collected by means of a General Oceanics rosette system equipped with six 5 l Niskin bottles. An attached Neil-Brown STD was used for recording salinity and temperature. At each station water samples were collected at $4 \mathrm{~h}$ intervals over a $24 \mathrm{~h}$ cycle from 9.56 and $130 \mathrm{~m}$ depths, corresponding approximately with the depths of 69,10 and $0.5 \%$ surface irradiation as estimated from Secchi disc depth (Megard \& Berman 1989). Additional water samples from 500 and $1000 \mathrm{~m}$ were collected at the core station. All water samples were prefiltered through $300 \mu \mathrm{m}$ mesh Nitex net to eliminate large particles and zooplankton. Subsamples for bacteria and HNAN enumeration, and for determination of rates of bacterial production were processed without delay.

Water samples for the enumeration of HNAN and bacteria were preserved with the Lugol-Formaline decoloration technique (Sherr et al. 1989) and kept refrigerated. Cells were enumerated using epifluorescence microscopy and DAPI staining (Porter \& Feig 1980). We classified as 'HNAN' all nucleated, nanoplanktonic $(<20 \mu \mathrm{m})$, non-pigmented organisms, and distinguished them from chlorophyll-containing cells by their fluorescence characteristics. Biovolumes of HNAN were estimated from microscopically measured linear dimensions and approximated geometrical shapes.
Bacterial production was measured using the [methyl $-{ }^{3} \mathrm{H}$ ] thymidine (TdR) incorporation method (Wicks \& Robarts 1987). Working solutions of TdR (41 $\mathrm{mCi} \mathrm{mmol}{ }^{-1}$; Amersham, UK) were made daily with $0.2 \mu \mathrm{m}$ filtered, autoclaved, double-distilled water. For each sample, triplicate $25 \mathrm{ml}$ subsamples were placed in sterile polystyrene scew-top tubes immediately upon collection; 2 were live replicates, 1 an $\mathrm{NaOH}$-killed (1.25 $\mathrm{ml}$ of $5 \mathrm{~N} \mathrm{NaOH}$ ) control. Labeled thymidine was added to each incubation tube to give a final concentration of $18 \mathrm{nM}$, a concentration that should fully inhibit de-novo DNA synthesis (Bell 1990). The tubes were incubated at air temperature (ca $25^{\circ} \mathrm{C}$ ) for $60 \mathrm{~min}$. In a preliminary experiment the uptake of TdR was found to be linear over $4 \mathrm{~h}$. Thymidine incorporation in the live tubes was stopped by the addition of $5 \mathrm{~N} \mathrm{NaOH}$. After 15 min labeled DNA was precipitated in ice-cold TCA, collected on $0.2 \mu \mathrm{m}$ poresize celluiose nitrate membrane filters, washed with phenol-chloroform $(50 \% \mathrm{w} / \mathrm{v})$ and then $80 \%$ ethanol. After removing the non-filtering area, the filters were dissolved completely in $0.75 \mathrm{ml}$ of ethyl acetate and placed in $5 \mathrm{ml}$ of scintillation cocktail $(70 \%$ toluene, $30 \%$ Lumax; Lumac, Belgium). Tritium incorporation into DNA was determined with a liquid scintillation counter and counts were corrected for quench (with an external standard) and machine counting-efficiency. Replicate TdR incorporation rates were usually within $20 \%$. Bacterial cell production was calculated using the conversion factor of $1 \times 10^{18}$ cells produced $\mathrm{mol}^{-1}$ TdR incorporated (Moriarty 1988, Bell 1990).

Detailed depth profiles of temperature, salinity, nutrients, chlorophyll and picoplankton abundance were measured concurrently by others (Krom et al. 1992, Wood et al. unpubl.). Water temperature ranged from $27.3^{\circ} \mathrm{C}$ at the surface to $16.4^{\circ} \mathrm{C}$ at $130 \mathrm{~m}$ at the core station and from $26.2^{\circ} \mathrm{C}$ to $16.3^{\circ} \mathrm{C}$ at the boundary station. Temperature and salinity profiles at both stations showed a surface mixed layer of about $40 \mathrm{~m}$, consisting of high salinity warm water, below which was a 10 to $20 \mathrm{~m}$ layer of low salinity water of Atlantic origin (Brenner et al. 1991). Beneath the Atlantic water was a homothermal and constant salinity thermostad, extending down to $400 \mathrm{~m}$ at the core station, and down to $150 \mathrm{~m}$ at the boundary station (Brenner et al. 1991), indicating that the core station was well within the eddy. At both stations the temperature, salinity and nutrient depth profiles showed minor changes over $24 \mathrm{~h}$ (Wood et al. unpubl.), suggesting that the same parcels of water were sampled over time.

Nitrate concentrations at 9,56 and $130 \mathrm{~m}$ ranged from 0.32 to $1.35 \mu \mathrm{M}$ at the core station and from 0.02 to $0.49 \mu \mathrm{M}$ at the boundary, while phosphate concentrations ranged from undetectable to a maxi- 
mum of $0.04 \mu \mathrm{M}$ (Krom et al. 1992). Significantly higher nutrient concentrations were found at $500 \mathrm{~m}$ and $1000 \mathrm{~m}$ at the core station. At our sampling depths within the upper $130 \mathrm{~m}$ chlorophyll a concentrations ranged between 21 and $87 \mathrm{ng} \mathrm{l}^{-1}$, and were highest at $130 \mathrm{~m}$ and lowest at $9 \mathrm{~m}$. The highest chlorophyll concentration occurred at about $100 \mathrm{~m}$ at both stations and did not exceed $130 \mathrm{ng} \mathrm{l}^{-1}$ (Krom et al. 1992).

\section{RESULTS AND DISCUSSION}

Cho \& Azam (1990) claimed that bacterial abundance in the ocean's euphotic zone has a lower threshold of ca $3 \times 10^{5}$ cells $\mathrm{ml}^{-1}$. Bacterial numbers from the Cyprus Eddy clustered around this value, with numbers below the threshold occurring at the base of the euphotic zone at $130 \mathrm{~m}$ (Fig. 1). The bacteria were generally small $(<0.3 \mu \mathrm{m})$ coccoid or rod-shaped cells. At the core station bacterial numbers ranged between $7.9 \times 10^{4}$ and $2.4 \times 10^{6}$ cells $\mathrm{ml}^{-1}$, with a mean value of $4.9 \times 10^{5}$ cells $\mathrm{ml}^{-1}$. Bacterial numbers were generally higher at $9 \mathrm{~m}\left(\bar{x}=6.6 \times 10^{5}\right.$ cells $\left.\mathrm{ml}^{-1}\right)$ and $56 \mathrm{~m}\left(\bar{x}=5.9 \times 10^{5}\right)$ than at $130 \mathrm{~m}$ $\left(\bar{x}=2.2 \times 10^{5}\right)$. Bacteria numbered $2.4 \times 10^{4}$ cells $\mathrm{ml}^{-1}$ at $500 \mathrm{~m}$ depth and $1 \times 10^{4}$ at $1000 \mathrm{~m}$ depth. At the boundary station bacterial numbers were generally lower than at the core (Fig. 1). The mean was $2.8 \times 10^{5}$ cells $\mathrm{ml}^{-1}$, with highest numbers at $56 \mathrm{~m}(\bar{x}=4.7$ $\times 10^{5}$ cells $\mathrm{ml}^{-1}$ ), about half of that at $9 \mathrm{~m}$, and about a fourth at $130 \mathrm{~m}$.

Bacterial production at the core station

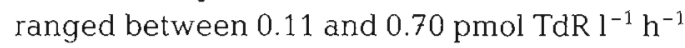
over $24 \mathrm{~h}$. The mean rate was $0.39 \mathrm{pmol} \mathrm{l}^{-1} \mathrm{~h}^{-1}$ with highest values usually occurring at $9 \mathrm{~m}$ depth (Fig. 1). At $500 \mathrm{~m}$ the rate was $0.09 \mathrm{pmol}$ $\operatorname{TdR~} \mathrm{l}^{-1} \mathrm{~h}^{-1}$, while at $1000 \mathrm{~m}$ the rate was below detection level. At the boundary station thymidine incorporation rates were generally lower than at the core station, ranging between 0.13 and $0.56 \mathrm{pmol} \mathrm{TdR} \mathrm{l}^{-1} \mathrm{~h}^{-1}$, with a mean rate of $0.24 \mathrm{pmol} \mathrm{TdR} \mathrm{l}^{-1} \mathrm{~h}^{-1}$.

No diel pattern of bacterial numbers or the rates of TdR incorporation was found at either station. However, when bacterial production rates were expressed as specific rates per bacterial cell $\left(10^{-21} \mathrm{~mol}\right.$ TdR incorporated cell $\left.{ }^{-1} \mathrm{~h}^{-1}\right)$, a distinct pattern appeared at both stations (Fig. 1). The cell-specific rates ranged between 0.10 and $7.43 \times 10^{-21} \mathrm{~mol}$ TdR cell ${ }^{-1} \mathrm{~h}^{-1}$ at the core station, and 0.12 and $9.62 \times 10^{-21} \mathrm{~mol} \mathrm{TdR}$ cell ${ }^{-1} \mathrm{~h}^{-1}$ at the bound- ary. The cell-specific rates were high in the early morning hours, declined during the day to a minimum in the late afternoon (core station) or at night (boundary station), and increased again in the early morning hours. At both stations this pattern was most noticeable at $130 \mathrm{~m}$ depth. The rates of thymidine incorporation into DNA as well as the cell-specific rates in the eddy were low, but within the range of values reported from other oligotrophic seas, such as the Celtic (Joint \& Pomroy 1987) and the Sargasso (Jonas et al. 1988, Fuhrman et al. 1989).

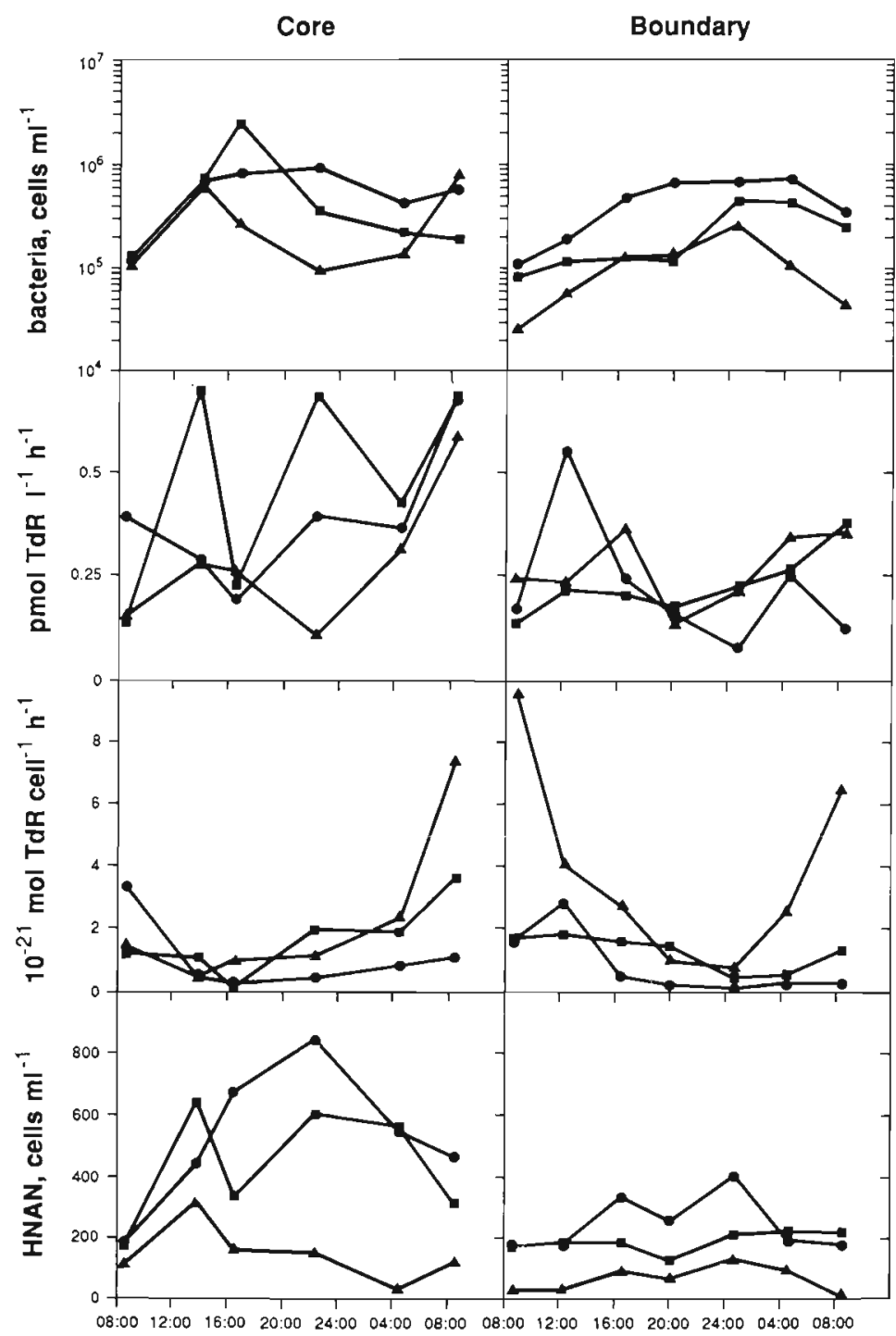

Time, $\mathrm{h}$

Fig. 1. Diel patterns of bacterial abundance (cells $\mathrm{ml}^{-1}$ ), rates of thymidine incorporation into DNA (pmol $\left.T \mathrm{TR}^{-1} \mathrm{~h}^{-1}\right)$, specific rates of thymidine incorporation per bacterial cell $\left(10^{-21} \mathrm{~mol} \mathrm{TdR} \mathrm{cell}{ }^{-1} \mathrm{~h}^{-1}\right)$, and of

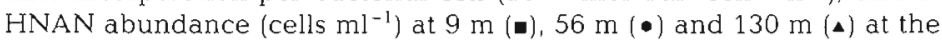
core and boundary of the Cyprus Eddy, Eastern Mediterranean Sea, September 1989 
Table 1 Bacterial production un a warm-core eddy in the Eastern Mediterranean Sea, September 1989. Values are averages of 7 measurements taken over $24 \mathrm{~h}$, except for the data from $500 \mathrm{~m}$ which was a single measurement

\begin{tabular}{|c|c|c|c|c|c|c|}
\hline Station & $\begin{array}{c}\text { Depth } \\
(\mathrm{m})\end{array}$ & $\begin{array}{c}\text { Thymidine } \\
\text { incorp. } \\
\left.\text { (pmol } l^{-1} h^{-1}\right)\end{array}$ & $\begin{array}{c}\text { No. of } \\
\text { cells } \\
\left(\times 10^{6} 1^{-1}\right)\end{array}$ & $\begin{array}{c}\text { Cell } \\
\text { production } \\
\left(\times 10^{6} \mathrm{I}^{-1} \mathrm{~h}^{-1}\right)\end{array}$ & $\begin{array}{c}\text { Specific } \\
\text { growth } \\
\left(\mathrm{d}^{-1}\right)\end{array}$ & $\begin{array}{l}\text { Doubling } \\
\text { time } \\
\text { (d) }\end{array}$ \\
\hline \multirow[t]{4}{*}{ Core } & 9 & 0.48 & 6.60 & 0.48 & 0.0175 & 57.3 \\
\hline & 56 & 0.39 & 5.90 & 0.39 & 0.0159 & 63.3 \\
\hline & 130 & 0.29 & 2.15 & 0.29 & 0.0318 & 31.4 \\
\hline & 500 & 0.09 & 0.24 & 0.09 & 0.0038 & 266.7 \\
\hline \multirow[t]{3}{*}{ Boundary } & 9 & 0.23 & 2.27 & 0.23 & 0.0243 & 41.1 \\
\hline & 56 & 0.23 & 4.69 & 0.23 & 0.0118 & 84.9 \\
\hline & 130 & 0.26 & 1.21 & 0.26 & 0.0516 & 19.4 \\
\hline
\end{tabular}

At the core station average diel bacterial cell produc-

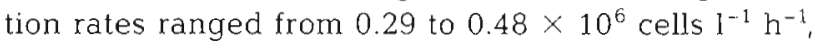
giving doubling times of 31.4 to $57.3 \mathrm{~d}$. At the bound-

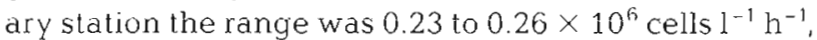
with doubling times of 19.4 to $84.9 \mathrm{~d}$. The single measurement from $500 \mathrm{~m}$ gave a doubling time of $267 \mathrm{~d}$. These doubling-time estimates are longer than reported elsewhere for bacteria in the euphotic zone (e.g. Fuhrman et al. 1989). A similar value of $65 \mathrm{~d}$ was reported by Cho \& Azam (1988) for bacteria in aphotic water of an oligotrophic north Pacific gyre.

Estimates of bacterial doubling times depend on the conversion factor employed for calculating bacterial cell production from TdR incorporation rates, the choice of which remains controversial. While Cho \& Azam (1988) used a factor of $1.18 \times 10^{18}$, similar to the $1.0 \times 10^{18}$ employed here, Ducklow (1986) used a value 4 -fold higher for calculating bacterial production in a Gulf Stream ring. Recently Bell (1990) argued that conversion factors that were considerably greater than the theoretical $1 \times 10^{18}$ were often obtained in experiments in which the amount of TdR added was insufficient to completely inhibit de-novo DNA synthesis.

Numbers of HNAN were higher at the core station compared with the boundary station, a pattern similar to that of bacteria (Fig 1). At the core station the HNAN numbers ranged between 36.5 and 851 cells $\mathrm{ml}^{-1}$ while at the boundary station the range was 18.5 to 413.7 cells $\mathrm{ml}^{-1}$. At both stations highest numbers were recorded at $56 \mathrm{~m}$ depth and lowest at $130 \mathrm{~m}$ depth.

The majority of the HNAN cells were small, usually 1 to $3 \mu \mathrm{m}$ in diameter. In all samples 93 to $99 \%$ of the cells had a diameter of $5 \mu \mathrm{m}$ or smaller. However, these small cells contributed only 25 to $44 \%$ of the overall HNAN biomass, while the rare large $(>5 \mu \mathrm{m})$ cells contributed the bulk of it.

The ratio of bacterial cells to HNAN cells was about 1000.1500, a ratio typical of aquatic systems (Azam et al. 1983). Considering the exceptionally low cellspecific thymidine incorporation rates and the long bacterial doubling times (Table 1), we would have expected a smaller standing crop of HNAN relative to bacterial numbers. Alternatively, the HNAN population could have been utilizing other food sources, e.g. prochlorophytes, thus exerting a low grazing pressure on bacteria. Wood et al. (unpubl.) found small-sized $(<0.5 \mu \mathrm{m})$ prochlorophytes to be abundant in the Cyprus eddy. Our hypothesis requires experimental confirmation.

The low values for bacterial abundance and production at both stations are in agreement with the exceptionally low nutrient and chlorophyll concentrations, and demonstrate again the ultra-oligotrophic nature of the Eastern Mediterranean Sea. The study did not reveal major differences between the core and boundary locations (Fig. 1). Higher bacterial standing crops and production, and greater differences in their vertical distribution between the eddy's core and boundary are anticipated to occur in winter, when deep mixing at the core (to ca $400 \mathrm{~m}$ ) brings nutrients into the euphotic zone, supporting a short (days to a few weeks) spike of new production (Krom et al. 1992).

Acknowledgements. The cruise was organized by $T$ Berman and sponsored jointly by GAP, IOLR, and the Israel Ministry of Science. We thank IOLR and Environment Canada for providing funds for the participation in the cruise of T.Z. and R.D.R., respectively, and the crew of the RV 'Shikmona' for help at sea. Bacterla were counted by Vijay Tumber and HNAN by Sara Chava.

\section{LITERATURE CITED}

Azam, F., Fenchel, T., Field, J. G., Meyer-Reil, L. A., Thingstad, F. (1983). The ecological role of water-column microbes in the sea. Mar. Ecol. Prog. Ser. 10: 257-263

Bell, R. T. (1990). An explanation for the variability in the conversion factor deriving bacterial cell production from incorporation of ${ }^{3} \mathrm{H} \mid$ thymidine. Limnol. Oceanogr 35: $910-915$ 
Berman, T., Townsend, D. W., El-Sayed, S. Z., Trees, C. C., Azov, Y. (1984). Optical transparency, chlorophyll and primary productivity in the eastern Mediterranean near the Israeli coast. Oceanol. Acta 7: 367--372

Berman, T., Walline, P. W., Schneller, A., Rottenberg J. Townsend, D. W. (1985). Secchi disk record: a claim for the eastern Mediterranean. Limnol. Oceanogr. 30:449-450

Berman, T., Azov, Y., Schneller, A., Walline, P., Townsend, W. D. (1986). Extent, transparency, and phytoplankton distribution of the neritic waters overlying the Israeli coastal shelf. Oceanol. Acta 9: 439-447

Bradford, M. R., Heath, R. A., Chang, F. H., Hay, C. H. (1982). The effect of warm-core eddies on oceanic productivity off northeastern New Zealand. Deep Sea Res. 29: 1501-1516

Brenner, S. (1989). Structure and evolution of warm core eddies in the eastern Mediterranean Levantine Basin. J. geophys. Res. 94: 2593-12602

Brenner, S., Rozentraub, Z., Bishop, J., Krom, M. (1991). The mixed layer/thermocline cycle of a persistent warm core eddy in the eastern Mediterranean. Dyn. atmos. Oceans 15: $457-476$

Cho, B. C., Azam, F. (1988). Major role of bacteria in biogeochemical fluxes in the ocean's interior. Nature, Lond 332: $441-443$

Cho, B. C., Azam, F. (1990). Biogeochemical significance of bacterial biomass in the ocean's euphotic zone. Mar. Ecol. Prog. Ser. 63: 253-259

Ducklow, H. W. (1986). Bacterial biomass in warm-core Gulf Stream ring 82-B: mesoscale distributions, temporal changes and production. Deep Sea Res. 33: 1789-1812

Falkowski, P. G., Ziemann, D., Kolber, Z., Bienfang, P. K. (1991). Role of eddy pumping in enhancing primary production in the ocean. Nature, Lond. 352: 55-58

Fuhrman, J. A., Sleeter, T D., Carlson, C. A., Proctor, L. M. (1989). Dominance of bacterial biomass in the Sargasso Sea and its ecological implications. Mar. Ecol. Prog. Ser. 57: $207-217$

Jenkins, W. J. (1988). Nitrate flux into the euphotic zone near Bermuda. Nature, Lond. 331: 521-523

This article was presented by T. Berman, Tiberias, Israel
Joint, I. R., Pomroy, A. J. (1987). Activity of heterotrophic bacteria in the euphotic zone of the Celtic Sea. Mar. Ecol. Prog. Ser. 41: 155-165

Jonas, R. B., Tuttle, J. H., Stoner, D. L., Ducklow, H. W. (1988). Dual-label radioisotope method for simultaneously measuring bacterial production and metabolism in natural waters. Appl. envir. Microbiol. 54: 791-798

Krom, M. D., Brenner, S., Kress, N., Gordon, L. I. (1991). Phosphorus limitation of primary productivity in the Eastern Mediterranean. Limnol. Oceanogr. 36: 424-432

Krom, M. D., Brenner, S., Kress, N., Neori A., Gordon, L. I. (1992). Nutrient dynamics and new production in a warmcore eddy from the E. Mediterranean Sea. Deep Sea Res. 39: $467-480$

Megard, R. O., Berman, I (1989). Effects of algae on the Secchi transparency of the southeastern Mediterranean Sea. Limnol. Oceanogr. 34: 1640-1655

Moriarty, D. J. W. (1988). Accurate conversion factors for calculating bacterial growth rates from thymidine incorporation into DNA: elusive or illusive? Ergebn. Limnol. 31. 211-217

Porter, K. G., Feig, Y S. (1980). The use of DAPI for identifying and counting aquatic microflora. Limnol. Oceanogr. 25: $943-948$

Salihoglu, I., Saydam, C., Basturk, O., Yilmaz, K., Gocmen, D., Hatipoglu, E., Yilmaz, A. (1990). Transport and distribution of nutrients and chlorophyll a by mesoscale eddies in the northeastern Mediterranean. Mar. Chem. 29: 375-390

Sherr, B. F., Sherr, E. B., Pedros-Alio, C. (1989). Simultaneous measurement of bacterioplankton production and protozoan bacterivory in estuarine water. Mar. Ecol. Prog. Ser. 54: $209-219$

Tranter, D. J., Parker, R. R., Cresswell, G. R. (1980). Are warm-core eddies unproductive? Nature, Lond. 284: $540-542$

Wicks, R. J., Robarts, R. D. (1987). The extraction and purification of DNA labelled with (methyl- ${ }^{3} \mathrm{H}$ ) thymidine in aquatic bacterial production studies. J. Plankton Res. 9: $1159-1166$

Manuscript first received: January 16, 1992

Revised version accepted: May 18, 1992 